УДК $122 / 129$

doi.org/10.33989/2075-1443.2019.41.172993

orcid.org/0000-0003-3053-0451

\title{
Свген Мулярчук
}

МУЛЯРЧУК Свген Іванович - кандидат філософських наук,старший науковий співробітник Інституту філософії імені Г.С. Сковороди НАН Украӥни. Сфера наукових інтересів - етика, екзистенційна філософія, філософська антропологія.

\section{«ДОСВІД НЕВИДИМОГО»: ПЕРЕЖИВАННЯ БУТТЯ, ЧУТТЯ I РОЗУМІННЯ У СУБ'ЄКТИВНОМУ ІСНУВАННІ ЛЮДИНИ}

У статті розглядається проблема достеменності особистісного досвіду людини. Запропоновано тему «досвіду невидимого» в аналізі виявлення буття у досвіді людини, чуття $i$ розуміння ї̈ власного суб'єктивного існування та існування інших людей. Показано домінуючий характер та пізнавальну обмеженість ідеї бачення у феноменологічному аналізі людського буття. Показано можливості звернення до досвіду пережсивання, чуття та розуміння в феноменологї і філософській антропології. Обгрунтовано релевантність поняття «переживання буття» на позначення неінтениійного досвіду буття як основи єдності інтенційних актів людської свідомості. Доведено засадниче значення здатностей чуття $i$ розуміння для формування особистісного досвіду людини.

Ключові слова: суб'єктивність, переживання буття, чуття, розуміння, особистість, існування, досвід невидимого

Орієнтація філософії, науки і взагалі цивілізації на бачення, слугує ідеалу знання, за яким приховане бажання людини володіти світом. Ця пізнавальна установка заснована на переконанні про те, що світ знаходиться у розпорядженні людини, що ті речі, які зовні існують незалежно від неї, все ж видаються їй у їхній суті. Бачення людини охоплює й невидиме для ока. Прилади помножують зорову силу, моделювання реальності і передбачення дають уявну картину того, що

(C) Є. І. Малярчук, 2018 
не може бути сприйнятим відчуттями, або чого ми поки ще не досягли. Бачення потенційно нескінченне, а його припинення асоціюється 3 небуттям. Ті люди, що не бачать на очі, мають інші сприйняття, посвоєму уявляють і розуміють світ. Принаймні кожен здатний на мислене бачення.

Метою даної розвідки є показати основи, сутність і значення тих здатностей та спрямувань досвіду людини, які не охоплюються феноменологією бачення, але є необхідними для розуміння буття людини. Засадничою у нашому розгляді є думка про конечність буття людини. Ми не породжуємо буття і лише намагаємося втримати його у світлі власного прагнення істини. Конечність людини - це не сама лише смертність, це розуміння меж можливого і нашого незнання найсуттєвіших речей та обставин власного існування. Взагалі, мислення, як показав Гайдеггер, інтерпретуючи «Критику чистого розуму» Канта, є справою конечних істот. Нескінченному Богові воно не потрібне, адже самим актом Божественного споглядання сущому дається буття (Хайдеггер, 1997: с. 13, 14). Бог все бачить, а людина лише прагне бути йому подібною. Проте у кожного з нас є бажання сягнути нескінченності, повірити в те, що поза межами зрозумілого й доступного нам відкриється щось більше. У цьому бажанні й вірі виявляється потреба священного. Адже неможливо секуляризувати єдине для кожного з нас буття і звести його до сприйняття лише осяжних речей та порядкування серед них у світі. Саме тому бачення людини не може бути останньою підставою істини.

Основна частина. Філософія, яка припускає думку, що речі самі по собі відмінні, ніж те, як ми їх сприймаємо у відчуттях, звільняє місце вірі. Ми пізнаємо світ як незавершений, ми відкриті до того, чого не можемо зрозуміти. Критика розуму необхідна, інакше думка людини про конечність буття стає руйнівною. Потрібно виходити за межі нами опанованого і підвладного. Для існування у цьому видимому світі нам важливо відкривати обрії нескінченності, вірити у безсмертя душі, буття Бога, або принаймні в моральну свободу особистості від світової причинності. Справді, без такої віри і відчуття моральної автономії думка людини безкінечно натикатиметься на глухі кути. Приймаючи на віру те, що буття всього сущого і нас самих має сенс, навіть коли не вдається знайти відповіді щодо його першопричин та інших запитань, які непокоять нас як смертних, ми спроможні брати на свою відповідальність власні дії у царині даного нашому розумінню. Нехай, як вчив Кант, ми пізнаємо лише феномени - те, як речі відкриті нашому сприйняттю та мисленню, але реальність нашої дії незаперечна і є такою, що зобов'язує перед іншими людьми та закликає давати принаймні самим собі звіт у власних вчинках. 
Насправді, філософія завжди спрямована на розуміння речей невидимих, налаштована на вихід поза достеменності сприйняття окремої людської свідомості, орієнтуючись на критерій інтерсуб'єктивності істини. Ми не маємо відчуття того, що бачить та переживання того, як мислить інша людина. Ми знаємо це лише з іiі слів, отже спираємося на досвід невидимого. Саме існування людської свідомості не є видимим, проте поза сумнівом для нас $є$ не лише власний досвід, але й суб'єктивність інших людей. Ми не бачимо також особистість іншої людини, але відчуваємо і розуміємо іiі, інтерпретуємо дані нашому сприйняттю феномени, як їі виявлення. У практичній взаємодії ми $\epsilon$ особами, очікуємо і отримуємо відповіді від інших та відповідаємо їм. Без цієї інтерсуб'єктивності була б неможлива і наша самосвідомість, і об'єктивність пізнання. Отже, видиме і невидиме так чи інакше узгоджуються у людському розумінні, і філософія працює з можливостями мислити їх зв'язок.

Ми постійно здійснюємо переходи між суб'єктивним та об'єктивним планами буття. Як і інші люди, ми переживаємо власне буття, співвідносимо цей досвід із сприйняттям нас зовні та з боку наших справ у світі, пояснюємо собі внутрішньо осягнуту мету буття та цілі визначені для нас іншими людьми. Всі продукти праці, результати творчості репрезентують здатність людей реалізувати їхнє власне розуміння й задуми. Спочатку існуючи лише ідеально, замислене нами стає втіленим у зовнішньо достеменному світі. Ми поділяємо з іншими людьми спільні поняття та апріорні припущення щодо цих вимірів видимого і невидимого. На такому поєднанні заснований людський світ. Наука також оперує знаками та символами умоглядних співвідношень і організовує матеріальний світ відповідно до них. У суспільному бутті уявлення про сутність людини формують норми та цінності співжиття, які стають регулятивами зовні спостережної поведінки.

Невидиме виявляється у чутті та розумінні людини. Ці два види інтуїтивного знання взаємопов'язані, але потрібно розрізняти їх за типом основного для них досвіду, за їх інтенційністю. Перше має характер переживання, друге - мисленого бачення. Спочатку існує переживання нашого буття, і в його потоці виявляється наше чуття себе завжди співвіднесене з відкриттям присутності чогось потенційно значущого зовні нас. Щоб розуміти виявлене у нашому досвіді, ми поміщаємо його у невидимий мислений простір, організований за образами та аналогіями баченого нами світу. Таким є і досвід невидимого. Так Бога вважають світовим володарем, а немислимість майбутнього неіснування у світі себе та інших людей трансформується в нашу уяву про потойбічне буття. Тобто початкове буттєве переживання має вли- 
тися у форму якогось бачення, щоб став можливим досвід. Здатності чуття і розуміння задіяні у цьому оформленні досвіду людини.

За інтенційністю чуття, яке існує на основі досвіду переживання, i розуміння, дане як мислене бачення, відмінні. Мислене бачення спрямоване на об'єкти, наближає свій предмет, дозволяє тримати його при собі, засвоювати його. Водночас воно досягає загальної зрозумілості та інтерсуб'єктивної достеменності. Пояснюючи щось іншим, ми кажемо «дивись», маючи на увазі «слідкуй за моєю думкою». Чуття ж інтровертивне. Сказавши «я так відчуваю», ми висловлюємо щось, що не обов'язково доводити, і маємо на увазі «повір мені». Сама основа досвіду виявлена у переживанні не об'єктивується, іiі неможливо переказати, але у ній ми відкриті для співіснування з іншими людьми. Існує апріорі свідомого буття людини. У психологічному сенсі «переживання», як чуття самого себе в певному стані, нетранзитивні, принаймні не завжди можуть нами передаватися. Інша людина зовсім не зобов'язана переживати те ж саме, що й ми. Але ми можемо бажати співпереживання, просити цього. У такому співчутті ми вже стаємо на щабель розуміння спільного, виявляємо здатність повірити почуттям іншої людини та співставити їх з власним досвідом і розумінням буття. Ми не можемо заступати іншого у його переживанні себе самого, але ми знаємо, що його хвилює, що займає його увагу.

Переживання $є$ досвідом буття на неінтенційному рівні, у ньому ми ще не можемо виділити себе. Чуття ж, як інтенційно визначене переживання нами себе й іншого, вказує на те, що є достеменним поза нашими налаштуваннями. Чуття індивідуальне, його даності виводяться в обрії спільного з іншими світу, коли стають ідеальними об'єктами мисленого бачення. Кожне чуття і розуміння $є$ у собі повним та завершеним елементом досвіду. Неможливо недочути внутрішньо, чогось недобачити мисленим поглядом, але можливо бути нерозвиненим у цих здатностях. Проте ми завжди маємо якийсь, нехай зі стороннього погляду обмежений і невірний, але для нас достеменний досвід самих себе й буття іншого у світі. Втім, зовні можемо вдавати, що чогось не відчуваємо і не розуміємо.

Засадниче значення здатностей чуття і розуміння для формування досвіду людини покажемо на прикладі засвоєння даних матеріальних відчуттів. Усі людські відчуття, викликані зовнішніми об'єктами, переживаються в суб'єктивно єдиному досвіді нашого само-буття, вони $є$ нашими, стосуються нас як одного і того ж суб'єкта. За класичним переліком існують п'ять видів відчуттів - запаху, смаку, дотику, зору, слуху, які можливо назвати матеріальними, зумовленими впливом ззовні. До них додають шосте - інтуїцію - результат внутрішнього чуття та 
розуміння людини водночас. Інтуїція являє собою суб'єктивний синтез досвіду. Дані від зовнішніх за походженням джерел співвідносяться $з$ чуттям та розумінням нами себе у світі в індивідуальній ситуації нашого буття. Сама мова підказує нам, що «інтуїтивно відчути» та «інтуїтивно зрозуміти» рівноправно вживані вислови. Ми маємо досвід себе у світі, спів-відчуваючи внутрішньо і зовні нам дане та виходячи 3 апріорної розумності світу. Цей взаємозв'язок об'єктивного та суб'єктивного планів досвіду демонструє, наприклад, чуттєве забарвлення особистих реакцій на впливи ззовні та події в людському світі. Так щось у діях інших може бути нам внутрішньо неприємним до відрази, немов на запах. Зовнішній вид чогось зробленого іншими людьми може асоціюватися зі смаком або несмаком. Щось побачене або почуте торкається якихось «струн» нашої особистості, серця, «бере за живе». Інші сприйняття домальовуються в картинах нашої уяви як знаки чогось, наприклад, омріяного або жахливого. Нарешті, щось сказане або і не голосове може сприйматися як те, що кличе нас.

Те, що досвід чуття і розуміння не зводиться до опрацювання даних матеріальних відчуттів підтверджується повсякденним досвідом. У нас самих та поза нами є багато того, що зрозуміти ми не можемо, але достеменність чого переживаємо. Менше за все ми знаємо самих себе в об'єктивному сенсі. Ми дані собі суб'єктивно, але це необ'єктивне чуття і розуміння себе необхідне, щоб сприймати i розуміти будь-що зовні. Ми відчуваємо і розуміємо водночас, і тому наше внутрішнє чуття не $є$ безпредметним, у ньому щось вже виявлене у своїй сутності. Така одночасність суб'єктивних здатностей людини коріниться у переживанні буття. Ми вводимо це поняття як умову єдності внутрішнього та зовнішнього планів досвіду. Переживання онтологічне. Особистісний досвід вибудовується, коли потік переживань суб'єктивно оформлений та спрямований у світ в інтенціях чуття та розуміння. Але й у зворотньому напрямку дійсне те, що все у світі отримує свою буттєвість, місце у бутті, лише коли воно співвіднесене 3 нашим суб' єктивним чуттям і розумінням, тобто досягаючи буттєвої основи нашого переживання.

Чуття ми відрізняємо від почуттів. Наше чуття і розуміння відкриває світ і суще у його бутті, адже лише через кожного з нас виявляються буттєві обрії. У той же час почуття людини завжди вже захоплені сущим та їі стосунками $з$ іншими у світі. Почуття мають втіленість, співмірні і спільно зрозумілі нами у світі. Тому іноді ми марно намагаємося їх приховати від інших людей, вони зчитуються з нашого вигляду та настрою. Натомість досвід чуття незрозумілий іншим, поки ми не сформулюємо його, не знайдемо способу вираження. Чуття не 
виказує іншим свій об'єкт. Зрозумілу його об’єктність ми задаємо, визначаючи, що є його джерелом і предметом. Таким чином, чуття i poзуміння формують «що» нашого переживання. Зазвичай ми прагнемо пояснити свої переживання іншим у вигляді оповіді про те, що ми відчуваємо, тобто вказуючи на певну предметність. Коли ж нам самим власне чуття видається безпредметним і незрозумілим, ми стурбовано шукаємо, що його викликало, намагаємося подолати нерозуміння ситуації, об'єктивувати іiі. Така тривога має знайти джерело, наприклад, страх небуття має вдягнути маску смерті... Існують і більш матеріальні аналогії. Так, локалізоване відчуття болю є потенційно зрозумілим, але біль невідомого походження заполоняє нас. Ми маємо опредметнити чуття, щоб встановити його причину і перетворити його на відчуття, звертаємося для цього до іншої особи, до лікаря, який оглядає наше тіло як об'єкт, як щось зовнішнє, стосовно чого можливо мати знання, встановити діагноз. Звісно, внутрішнє буттєве чуття та фізичний біль - це різні феномени. Чуття болю є переживанням, яке може поневолити нашу душу, наше буття, але ми також 3 ним живемо і боремося. Часто воно є таким, що не має фізичної причини. Нам іноді боляче згадувати про щось, жити з якоюсь думкою. Фізичне ж відчуття болю є сигналом про щось руйнівне для тіла, щось здатне нас у ньому паралізувати. I ми намагаємося встановити і подолати його причини заради власного буття, заради можливості мати чуття і розуміння себе.

Переживання буття, як основа будь-якого можливого досвіду людини, є власне виявом неінтенційного буття самої свідомості, вможливлює єдність суб’єктивного досвіду. Потік переживань несе у собі наші внутрішні та зовнішні відчуття, інтуїтивні осягнення та акти мислення. Ми самі і кожен об'єкт наших інтенцій “є” у цьому переживанні. Незалежно від того, як ми себе розуміємо, ми є, переживаємо власне буття. Будь-які об'єкти дані на фоні нашого переживання, icнуючі й уявні. Інтенційні акти - це сфокусовані переживання. Чуття $\epsilon$ проекцією мого переживання буття на предмет досвіду, яким можу бути я сам, інша істота, річ або ситуація. І розуміємо ми, кожен як конкретна, конечна особа, лише те, що виявляється у цій проекції нашого переживання буття у світ. Переживання буття індивідуальне і неподільне. Саме тому видимі й невидимі речі ми сприймаємо і розуміємо кожен по-своєму, хоча вони й співвідносяться із зовнішніми об'єктами, стосовно яких можлива спільна думка людей. I саме у неповторність переживання буття занурена й укорінена наша індивідуальність.

На основі достеменності переживання буття ми маємо чуття себе, i наше мислене бачення, інтенційно надбудовуючись над цим чуттям, стверджує нашу позицію як суб'єкта у цілісності світу та в просторі 
нашого місцеперебування. Ми фіксуємо об'єкти мисленого бачення у позачасовому вимірі або маємо розуміння їхньої часовості, досвід якої $€$ нашим внутрішнім, співвіднесеним з переживанням буття. Сприйняття та мисленнєві акти мають послідовність і часове тривання у потоці переживань, де одні елементи досвіду змінюються іншими.

Ми можемо перебувати у розпачі та нерозумінні, але єдність нашого «я» зберігається глибше і поза нашої рефлексії - в чутті себе як центру переживань. Наше знання себе, звісно, формується та уточнюється у спілкуванні з іншими людьми, але сама суб' єктність задана досвідом чуття, зокрема й втіленості, яка в феноменологічному сенсі $€$ не матеріальною, а екзистенційною. Тіло, як це показав Мерло-Понті, $\epsilon$ способом існування людини у світі, ми не відділяємо себе від нього (Мерло-Понти, 1999). Без такого чуття самих себе, як умови ставлення до зовнішніх нам речей, не було б ніякої об'єктивності. Власну суб'єктивність ми переживаємо в досвіді чуття і осягаємо зовнішній світ у сприйняттях, розуміємо себе і пізнаємо інше. Очевидно, що і в стані божевілля не переривається переживання буття, але відбувається порушення інтенційних зв'язків. Людина $\epsilon$, отже має переживання, однак цілісність іiі чуття і розуміння себе сплутана, їй бракує співвіднесення з досвідом інших для адекватної взаємодії у світі. Вільний від себе і «вільний від Бога» не є суб' єктом відповідальності. У його бутті немає міри і мети.

В онтологічному сенсі буття не є об'єктивним, ми переживаємо його, і лише так можемо розуміти і говорити про нього. I себе самого як особистість неможливо побачити та зрозуміти поза цим переживанням. Все видиме і невидиме, зрозуміле і незрозуміле, існує, тобто «є», для нас на основі цього переживання. Внутрішній досвід людини формується 3 переживання буття та іiі чуття і розуміння себе. Само-чуття $є$ умовно першим щодо само-розуміння. Наша мова свідчить про такий порядок: «відчуваєш і зрозумів», а не зворотнім чином. Чуття себе генетично випереджає інші сприйняття. Все бачене і почуте нами виявляється на тлі чуття невидимого і невимовленого. І досвід тих, хто не чує «на слух», можливий, оскільки існує внутрішнє неслухове чуття. Так ми відчуваємо, наприклад, небезпеку або радість. Це даності чуття, виявлені інтенційно у початковому потоці наших переживань, у нашому спрямуванні на те чи інше, в контексті набутого досвіду, всього освоєного або визначеного як непідвладне нам. Багато того, що ми переживаємо і з чуттям чого живемо, ніколи не буде нами побачене. I про більшість ще невідомого ми спершу чуємо, а потім уявляємо і розуміємо.

Чуття незаперечно свідчить про те, що переходить межі тілесного існування. Так, ми є власним тілом, через тіло феноменально нам даний 
світ. Однак те, що стається з тілом, все ж відчувається як щось, що або підкоряється нашому бажанню, або ж діється проти нас, тобто як щось зовнішнє щодо нас. Ми маємо самопочуття, чуємо себе в тілі, сприймаємо себе втілено, але наше переживання буття позатілесне, і відповідно можливе чуття себе вільним від тіла. Смерть, яка має статися як факт тілесного існування, страшить нас не лише через уяву про втрату нами буття у світі, але як загроза втрати чуття самості. Не загибель тіла, а нищення цього чуття і розуміння себе сприймається як жах небуття. Смерть - це зупинка само-чуття й само-розуміння. Перетворення душі по смерті на духовну монаду, переживання буття якої законсервоване, яка не має «вікон» і не відчуває себе, дорівнює небуттю. Натомість, нас не так вже й гнітить думка про втрату тіла, коли ми налаштовані на те, що наше переживання буття не закінчиться і що ми матимемо на цій основі чуття й розуміння себе в якомусь іншому вимірі. І смерть близьких була б мабуть наполовину легшою, якби ми зберігали певність у збереженні їхньої суб’єктивності, здатності чути і відповідати нам.

У переживанні буття немає меж і розрізнень. А здатність чуття вже спрямована у світ. Сприймаючи себе у світі, ми маємо досвід конечності буття, але й відкриваємо спосіб виходити поза власні межі. Інше також інтенційно дане нам в чутті. Досвід чуття внутрішньо наповнює нас, розширює наші обрії та спонукає дослухатися до себе і до того, що приходить ззовні. У своєму чутті ми не пануємо над світом, не привласнюємо його, але й тому маємо можливість не жити своїми межами, не мати власну конечність за останню істину. Налаштування чути, засноване на переживанні буття людиною, спонукає їі відповідати за себе, перед собою та іншими. Ми саме спів-чуваємо іншим і тоді розуміємо те, що відчувають вони. Ми відкриваємо іншим свої почуття, оскільки у такому досвіді ми не замкнені.

На відміну від зорового чи іншого тілесного сприйняття, чуття не є миттєвим, блискавичним, подібно до враження від світла, яке сліпить, і коли від баченого затьмарюється розум. Чуття пробуджує. Воно триває, не співпадаючи з фізично почутим. Коли наше чуття було зворушене, ми згодом повертаємося подумки до почутого або відчутого раніше. Так, у щоденному житті, у співіснуванні з людьми ми чуємо про щось іноді не раз, перш ніж сприймемо це та відчуємо його істинність або хибність, долучимо до свого світобачення. Знайомі ідеї, байдужі слова, вкотре сказані кимось, якоїсь миті досягають мети, проникають через оболонки наших усталених уявлень, коли щось у нас таки відгукнеться, щось раптом зрушиться з місця, і почне жити у нашому світі - й тоді ми ясно «бачимо», тобто й розуміємо сказане в контексті власного існування. 
Чуттям ми назвемо те, що може вмістити у собі сенс, поєднуючись із розумінням. Це необов'язково потребує слуху. Ми «чуємо»у собі голос, який є думкою - словом сказаним собі, або ж словом іншого, коли ми готові його зрозуміти. Чути ж у собі голос зненацька, як щось стороннє, не пов'язане з пережитим, невидиме і фізично непояснене - це або божевілля, або релігійний «жах і тремтіння». Таке слово проймає людське єство і розтинає зрозумілий світ. Так чув біблійний Авраам до себе поклик Божий, який поклав край людським міркуванням. Поза душевною хворобою та містикою, про які ми не можемо тут вести мову, чуття спрямовує до зрозумілої мети, кличе у світ, дає знати, засвідчує щось для нашого розуміння. Внутрішньо відчуте і собі сказане не $є$ продуктом самої моєї свідомості, але $\epsilon$ тим, що зі мною відбувається, що мене стосується. Чуття розмикає наші межі. У ньому виявляється спрямування і вимога - те, що потрібно розуміти, на що нам відповідати і що підтверджувати у своєму існуванні.

Людина налаштована на чуття слова й розуміння сенсу. Через Слово, як каже «Біблія», все почало бути. Словом ми і живемо. Не володіючи істиною, ми відчуваємо потребу в ній бути. Не маючи ясного бачення, віримо «на слово» іншим, ввіряємо істину своїм словам. Говоримо ми мовою глибокою або й не надто багатою, вміло чи невдало, але намагаємося висловити щось за вагою рівне тому, що ми існуємо. Власне, кожне сказане слово засвідчує наше існування. «Мова - дім буття» - вже афористичний вислів Гайдеггера. Ми начебто намагаємося вмістити буття у мові. Лише його знецінення робить зайвими слова та зусилля думки. Чуття нематеріальне. Матеріальні об'єкти є джерелом звуку, але не сенсу. Чуття ж має сенс.

Отже, ми покладаємо неінтенційне переживання буття в основу здатності людини до інтенційного чуття і розуміння. Без буттєвого потоку переживань неможлива єдність цих та інших актів свідомості. Початок свідомого буття людини неможливо відслідкувати - це наближення до межі невідомого. Тому наше міркування про генетичну першість переживання буття $є$ гіпотетичним. Уявімо, однак, що з безпосереднього переживання буття людина згодом виявляє власне чуття себе і світу, яке посилюється і поєднується з їі розумінням. Можливо говорити про тривалий період становлення людської особистості, про розвиток мислення, але для появи самосвідомості первинна здатність переживання буття має бути притаманна людині апріорі, від народження.

Переживання буття можливо образно уявити як вісь або як джерело само-буття людини, яке з досвідом приростає і концентрується у іiі чутті та розумінні себе. Це переживання самісне, а вже здатності чуття і розуміння особистісні, сфокусовані і спрямовані. Неповторність пе- 
реживання буття задає індивідуальність нашого чуття себе і світу, i на його стрижні збирається досвід, вибудовується структура особистості, формується саморозуміння кожного з нас. Переживання буття забезпечує первинну єдність та неперервність людського досвіду. Воно постійно $\epsilon$, тоді як чуття людини подієве, спрямованості її розуміння змінюють об’єкти. Таким чином, на поверхні нашого досвіду збираються враження, але іноді щось раптом проймає його шари до осердя самого буттєвого переживання і пробуджує відцентровий рух само-буття, в якому ми відкриваємося у світі.

Переживання буття має бути притаманним всім живим істотам, яким ми приписуємо індивідуальне існування. Для того, щоб мислити осібну центрованість живих істот у світі, наприклад, таких високоорганізованих тварин, як ссавці, ми маємо допускати їхню здатність переживати буття. Хто з нас, маючи досвід спільного життя 3 хатніми улюбленцями, не вірить у їх переживання? Можливо, ми не скажемо про співчуття, предмет якого мав би бути відомим обом сторонам, але без сумніву тварини здатні вловити саму нашу емоцію, хвилю переживання у нас і відповісти їй. Спів-буття різних істот виявляється принаймні через таке співвіднесення їхніх переживань. Ми не знаємо, яке чуття самих себе для інших істот можливе і притаманне в дійсності, якою $є$ їхня здатність розуміти себе. Наприклад, Г. Плеснер, один 3 основоположників філософської антропології, заперечував можливість, що тварини ставляться до себе, натомість відзначав особливість людського самопереживання. Тварина позиціонована у своєму центрі, переживає зовнішнє, але у неї немає рефлексії, зворотного ставлення до себе. Людина екс-центрична у іiі позиціонуванні, тобто виходить поза свій центр і знає себе, «вона не лише живе й переживає, але й переживає своє переживання» (Плеснер, 2004, с. 254).

Переживання буття $є$ глибшим у свідомості, ніж особистісна ідентичність. Тому й свідомість інших істот можливо уявити і визнати, принаймні як наявність потоку їх переживань. Вони виявляють буття, не маючи його ідеї, думки про нього. Їхнє переживання до-особистісне. А ось вже інтенційний досвід чуття і розуміння людини фундує саме відому кожному в собі суб’єктивність. Як висновок, відзначимо, що філософська інтуїція буття необхідно спирається на цей досвід переживання та виявлені на його основі інтенції чуття і розуміння людиною себе у світі. В такий спосіб людина ставиться до себе та до інших людей, має власну ціннісну позицію, бажання збагнути сенс буття та тугу за трансцендентним - тим, що переходить осяжні для неї межі. Цей досвід знаходить своє вираження, набуває сенсу в кожному сказаному нами слові. 


\section{Список використаних джерел}

Мерло-Понти М. Феноменология восприятия : пер. с франц. Санкт-Петербург : Наука, Ювента, 1999. 605 с.

Плеснер X . Ступени органического и человек: Введение в философскую антропологию / пер. с нем. Москва : Российская политическая энциклопедия (РОССПЭН), 2004. $368 \mathrm{c}$.

Хайдеггер М. Кант и проблема метафизики / пер. с нем. Москва : Русское феноменологическое общество, 1997. 176 с.

\section{Referencec}

Khaidegger, M. (1997). Kant i problema metafiziki [Kant and the problem of metaphysics]. Moskva: Russkoe fenomenologicheskoe obshchestvo [In Russian].

Merlo-Ponti, M. (1999). Fenomenologiia vospriiatiia [Phenomenology of perception]. Sankt-Peterburg: Nauka, Iuventa [In Russian].

Plesner, Kh. (2004). Stupeni organicheskogo i chelovek: Vvedenie v filosofskuiu antropologiiu [Organic Life and the Human: An introduction to philosophical anthropology]. Moskva: Rossiiskaia politicheskaia entciklopediia (ROSSPEN) [In Russian].

\section{Muliarchuk Y.I.}

\section{"THE EXPERIENCE OF INVISIBLE": EXPERIENCE OF BEING, SENSE AND UNDERSTANDING IN HUMAN SUBJECTIVE EXISTENCE}

Abstract. The article studies the problem of authenticity of human experience. The author gives the analysis of experience of existence under the heading "the experience of invisible". The position of the researcher is that the phenomenology of vision omits the basic spheres of human experience such as the sense and the understanding of being of the personality and of being of the other people and of being as a whole. The cognitional limitedness of the idea of vision in the phenomenological analysis of human existence also lies in its incapability to take into consideration the finiteness of human existence and the existential necessity of infinity and transcendence. Whereas the idea of experience of being comprehends the idea of infinity, the abilities of sense and understanding put human existence in the horizons of finite world, but do not shut the "doors" in it for the human self.

Invisible is actually the permanent sphere of human thought and philosophy always considers the interrelation between visible and invisible entities and sites of reality. Being in whole is invisible and its experience is unintentional, while sense and understanding fall under the concept of intentional experience of the self, the other people and other entities. The study determines that the experience of being holds the continuity and unity of human experience. The author argues that sense is prior to understanding in forming of the objects of experience. The experience of sense is also determined as deeper and basic in the relation to the material sensations and human feelings. For example, the phenomenon of internal voice has for the first instance the nature of sense and then of understanding. The intellectual intuition and mental vision are the core of objective experience in human understanding 
and have timeless character. Whereas the temporality of experience is based on the synthesis of sense and understanding in the experience of being.

The study examines the approaches for the research of the experience of being, of abilities of sense and understanding in phenomenology and philosophical anthropology. The author bases his arguments particularly on the phenomenology of perception of M. Merleau-Ponty with his analysis of embodiment and the anthropology of H.Plessner with his idea of eccentric positionality. The research establishes that co-existence of people and even of people with other living creatures is possible upon the common ability of experience of being. The evidence of that is the examples of sympathy between different living entities and people in the living world. However, the ability of sense and understanding as intentional acts are intersubjective and form the special reasonable realm of human world. They have the principal importance for the forming of human experience.

For the conclusion, the research proves the relevance of the concept of "experience of being" for the study of nonintentional experience of existence as a basis for unity of intentional acts of human consciousness. Philosophic intuition of being is always founded on this experience. The sense and understanding of a person in the world on this ground makes it possible for a person to regard oneself and the other people, to take own stand in the world, to understand the purpose of existence and to get over its limits.

Keywords: subjectivity, experience of being, sense, understanding, person, existence, experience of invisible 